\title{
SIDE EFFECTS OF AZOXYSTROBIN AND TEBUCONAZOLE FUNGICIDES ON COTTON LEAF WORM SPODOPTERA LITTORALIS (LEPIDOPTERA: NOCTUIDAE) UNDER LABORATORY CONDITIONS.
}

\author{
Ramadan, M. A. El-Kholy ${ }^{(1)}$; Mahmoud, M. M. El-Bamby ${ }^{(2)}$ and Mahmoud, M. M. El- \\ Hassawy ${ }^{(1)}$
}

1) Department of Plant Protection, Faculty of Agriculture (Cairo), Al-Azhar University, Egypt.

2) Department of Environment and Bio-Agriculture, Faculty of Agriculture (Cairo), Al-Azhar University, Egypt.

\begin{abstract}
The side effects of azoxystrobin (Amistar, 25\% SC) and tebuconazole (Toledo 43\% SC) fungicides on some biological aspects of Egyptian cotton leaf worm (ECLW) (Spodoptera littoralis, Boisd.) were investigated in comparison with the untreated control under laboratory conditions. The fourth instar larvae were fed for $24 \mathrm{hrs}$ on castor bean leaves (Ricinus communis L.) treated with different concentrations of the tested compounds. Food consumption was measured regularly throughout the feeding tests until pupation. The results clearly indicated that the two fungicides reduced the weight consumed leaves larva ${ }^{-1}$ and decreased the feeding ratio. The azoxystrobin fungicide was more effective than tebuconazole especially at higher concentrations. Both compounds reduced larval weight and increased larval mortality and larval durations (days). Furthermore, reduced pupation $\%$ and adult emergence, and increased pupal durations. These compounds reduced reproductive parameters of adults (fecundity and fertility) and increased sterility \%. The longevity of males and females was reduced.

The present study revealed that, in all cases, the toxic effects of azoxystrobin and tebuconazole on some biological aspects of the Egyptian cotton leaf worm were proportionally increase with the increase of the concentrations. The results clearly indicated that the azoxystrobin fungicide was more effective than tebuconazole on Egyptian cotton leaf worm (ECLW).
\end{abstract}

Key words: Azoxystrobin, tebuconazole, biological effects, The Egyptian cotton leaf worm, biological aspects.

\section{INTRODUCTION}

The Egyptian cotton leaf worm, Spodoptera littoralis (Boisduval) (Lepidoptera: Noctuidae) is one of the major insect pests that cause a considerable feeding damage to many of the important vegetables and field crops such as sugar beet, cotton, spinach, alfalfa, pepper, eggplant, tomato, potato, lettuce, bean, strawberry and some ornamental crops throughout the year in Asia, Europe and Africa including Egypt (Hosny et al., 1986; Bayoumi et al., 1998; Pineda et al., 2007; Said et al., 2012; Saleh et al., 2015; El-Sheikh, 2015 and Wahba, 2016). It is a polyphagous insect having about 112 host plants (Meisner and Nemny, 1992; Khidr et al., 2003 and Sherief et al., 2009).
Several reports indicate that numerous fungicides have side effects on non-target organisms especially on the insect pests such as Drosophila and their hymenopterous parasitoids (Delpueech and Allemand, 2011), Trichogramma atopovivilia (Pratisoli et al., 2010), Spodoptera litura (Srivastava et al., 2017), Spodoptera exigua (Adamski and Ziemmichi, 2004) and Spodoptera littoralis (Abd El-Aziz, Shadia and Mohamed, 2002; El-Kholy, 2005 and El-Sisi et al., 2016).

Therefore, the objectives of this study is to evaluate the effect of two fungicides i.e: azoxystrobin and tebuconazole (commonly used to control early and late blight on solanaceae crops) on some biological aspects of the Egyptian cotton leaf worm. 


\section{MATERIALS AND METHODS}

\section{A. The insect.}

The Egyptian cotton leaf worm (Spodoptera littoralis) colony were obtained from Plant Protection Research Institute (PPRE), Agriculture Research Center (ARC), Dokki, Giza, Egypt. This strain were reared for 10 generations without exposure to any pesticides. The larvae were reared in laboratories of Department of Plant Protection, Faculty of Agriculture, Cairo, Al-Azhar University. They maintained on clean fresh castor bean leaves, Ricinus communis L., in a controlled environmental chamber at $25 \pm 2{ }^{\circ} \mathrm{C}$ and $65 \pm 5 \%$ R.H. and a photoperiod of $12: 12$ hrs. (L:D) as a method described by ElDefrawi et al. (1964).

\section{B. The treatments.}

\section{1- Tested fungicides:}

Two fungicides were used in this study at different concentrations. The azoxystrobin fungicide (Amistar, 25\% SC) was used at 1, 5, $10,25,50,75$ and $100 \mathrm{ppm}$ while tebuconazole fungicide (Toledo $43 \% \mathrm{SC}$ ) was used at 1, 5, $10,25,50,100$ and $125 \mathrm{ppm}$. Some characteristics of these compounds are listed in Table (1).

\section{2- Bioassay:}

The leaf dipping bioassay method was used. The pre washed clean leaves of castor bean leaves ( $R$. communis) were dipped in aqueous solution of the abovementioned concentrations for each concentration of any pesticide for 15 seconds, and allowed to dry on paper towel at room temperature, then placed in glass jars (1.0 liter) with paper towel on the bottom. Leaves dipped in water served as control.

Newly moulted fourth instar larvae (one day old) with an average weight $20 \pm 3 \mathrm{mg}$ were starved for $3 \mathrm{hrs}$. before use to insure an empty intestine, before they placed in the jars. Five replicates (in each containing 10 larvae) were used in each concentration beside the control. The larvae were fed on treated leaves for 24 hrs. then, on fresh untreated leaves until the end of the larval stage. The jars were covered with muslin. The dead larvae and feces were discarded and larval mortality was observed daily, uneaten leaves and new fresh leaves were weighted daily after taking the natural loss of moisture in consideration (control 2).

At the end of larval stage, the consumed fresh leaves was corrected according to the method described by Ghanema, Hoda (2002) as follow:

Corrected weight of the consumed leaves= Cb / Ca X Ta.

\section{Where:}

$\mathbf{C b}=$ Initial weight of castor bean leaves before larval exposure.

$\mathbf{C a}=$ Final weight (after exposure to natural dryness for $24 \mathrm{hrs}$.) of leaves without larvae.

Ta $=$ Final weight of treated leaves after feeding the larvae for $24 \mathrm{hrs}$.

Daily weight (fresh basis) of consumed

Table (1): Some information of the used compounds.

\begin{tabular}{|c|c|c|c|c|}
\hline $\begin{array}{l}\text { Trade } \\
\text { names }\end{array}$ & $\begin{array}{l}\text { Common } \\
\text { names }\end{array}$ & IUPAC names & $\begin{array}{c}\text { Rate of } \\
\text { application* } \\
\text { /100 L. water } \\
\end{array}$ & $\begin{array}{l}\text { Source of } \\
\text { compounds }\end{array}$ \\
\hline $\begin{array}{l}\text { Amistar } \\
25 \% \mathrm{SC}\end{array}$ & Azoxystrobin & $\begin{array}{c}\text { methyl }(E)-2-\{2-[6-(2- \\
\text { cyanophenoxy)pyrimidin-4- } \\
\text { yloxy]phenyl }\}-3-\text { methoxyacrylate }\end{array}$ & $50 \mathrm{~cm}^{3}$ & Syngenta Co. \\
\hline $\begin{array}{l}\text { Toledo } \\
43 \% \text { SC }\end{array}$ & Tebuconazole & $\begin{array}{l}(R S) \text {-1-p-chlorophenyl-4,4-dimethyl-3- } \\
(1 H-1,2,4 \text {-triazol-1-ylmethyl)pentan-3-ol }\end{array}$ & $35 \mathrm{~cm}^{3}$ & $\begin{array}{l}\text { Rotam } \\
\text { Agrochemica } \\
\text { ls Co. }\end{array}$ \\
\hline
\end{tabular}

* According to the recommendations by Agricultural Pesticide Committee (APC), Ministry of Agriculture and Land Reclamation (2017). 
treated leaves/larva $=\mathbf{A}$ - B / C.

\section{Where:}

$\mathbf{A}=$ Initial fresh weight of treated leaves before feeding the larvae.

$\mathbf{B}=$ Corrected fresh weight of treated leaves after feeding the larvae.

$\mathbf{C}=$ Number of survived larvae.

Also, the following parameters were calculated at the end of larval instars as follow:

- Mean weight of consumed leaves $\operatorname{larva}^{-1}$ (gm).

- Feeding ratio (Wada and Manukata, 1968) = b / a $\times 100$.

\section{Where:}

$\mathbf{a}=$ Amount of fresh weight of leaves consumed in the control.

$\mathbf{b}=$ Amount of fresh weight of leaves consumed in the treatment

- Antifeedant index \% (AFI) according to Pavela et al. (2008) as follow:

$$
\text { AFI }=\{(C-T) /(C+T)\} \times 100 .
$$

\section{Where:}

$\mathbf{C}=$ Weight of leaves consumed in the control.

$\mathbf{T}=$ Weight of leaves consumed in the treatment.

- The larval weight (mg).

- The larval duration (days).

- The larval mortality \%.

Also, at pupal stage, the pupation \%, pupal mortality $\%$ and pupal duration (days) were recorded. At the adult stage, the adult emergence $\%$ was calculated.

Pairs of 2 males and 2 females resulted from each concentration of each pesticide were placed in glass jar (2 liter) containing Nereum oleander leaves as a site of egg laying. The jars were provided with pads of cotton soaked with a $15 \%$ sugar solution and covered with muslin. Pads of cotton were replaced daily when needed. Five replicates were used in each concentration beside the control treatment. The effect of these compounds on adult stage was calculated as follow:

- Reproductive parameters (fecundity and fertility)

Where:

Fecundity $=$ Number of deposited eggs female ${ }^{-1}$.

Fertility $=$ Egg hatchability $\%$.

- Sterility \% (Toppozada et al., 1966) as follow:

$$
=100-\{(\mathbf{a} \times \mathbf{b} / \mathbf{A} \times \mathbf{B}) \times 100\} .
$$

Where:

$\mathbf{a}=$ Number of eggs laid female ${ }^{-1}$ in the treatment.

$\mathbf{b}=$ Percent of hatchability in the treatment.

$\mathbf{a}=$ Number of eggs laid female ${ }^{-1}$ in the control.

\section{b = Percent of hatchability in the control.}

Percentages of mortality were corrected when needed according to Abbott's formula (Abbott, 1925).

\section{C- Statistical analysis.}

Statistical analysis was conducted by ANOVA and compared by L.S.D. test at 5\% and $1 \%$ level of probability in all experiments according to Gomez and Gomez (1984).

\section{RESULTS}

Data presented in Table (2) revealed the effect of treatments on food consumption. From these results, the fungicides clearly reduced the weight of consumed leaves larva ${ }^{-1}$ and decreased the feeding ratio. The tebuconazole fungicide gave lower effect than azoxystrobin especially at higher concentrations. The results also indicated that the toxic effect of these compounds on feeding was gradually increased with the increasing of concentration. The results in Table (3) showed the effect of compounds on larval weight, larval mortality and larval duration. The results showed that, all concentrations in the two fungicides reduced the mean weight of larva. The reduction in food consumption by larva in fungicides treatments was continued from the fourth instar to the end 
Table (2): Food consumption by Spodoptera littoralis $4^{\text {th }}$ instar larvae after feeding on fungicide treated leaves for $24 \mathrm{hrs}$. (at the end of larval instar).

\begin{tabular}{|c|c|c|c|c|}
\hline \multirow{3}{*}{ Treatments } & $\begin{array}{c}\text { Conc. } \\
(\mathrm{ppm})\end{array}$ & $\begin{array}{c}\text { Average weight of consumed } \\
\text { leave/ larva (gm) } \pm \mathrm{SE}^{*}\end{array}$ & $\begin{array}{c}\text { Feeding } \\
\text { ratio \% }\end{array}$ & $\begin{array}{c}\text { AFI** } \\
(\%)\end{array}$ \\
\hline Control & 00.00 & $3.21 \pm 0.30$ & 00.00 & 00.00 \\
\hline \multirow{4}{*}{$\begin{array}{c}\text { Toledo } \\
43 \% \text { SC }\end{array}$} & 01.00 & $3.00 \pm 0.27$ & 93.15 & 03.55 \\
\cline { 2 - 5 } & 05.00 & $2.90 \pm 0.26$ & 90.34 & 05.07 \\
\cline { 2 - 5 } & 10.00 & $2.72 \pm 0.28$ & 84.74 & 08.26 \\
\cline { 2 - 5 } & 25.00 & $2.54 \pm 0.30$ & 79.13 & 11.65 \\
\cline { 2 - 5 } & 50.00 & $2.21 \pm 0.19$ & 68.85 & 18.45 \\
\cline { 2 - 5 } & 100.00 & $2.08 \pm 0.06$ & 64.80 & 21.16 \\
\cline { 2 - 5 } & 125.00 & $1.74 \pm 0.27$ & 54.21 & 29.58 \\
\cline { 2 - 5 } Amistar & 01.0 & $3.04 \pm 0.31$ & 94.70 & 02.72 \\
\cline { 2 - 5 } & 05.0 & $2.83 \pm 0.33$ & 88.16 & 06.29 \\
\cline { 2 - 5 } & 10.0 & $2.71 \pm 0.36$ & 84.42 & 08.44 \\
\cline { 2 - 5 } & 25.0 & $2.48 \pm 0.45$ & 64.26 & 12.83 \\
\cline { 2 - 5 } & 50.0 & $2.06 \pm 0.09$ & 49.84 & 21.82 \\
\cline { 2 - 5 } & 75.0 & $1.60 \pm 0.27$ & 42.37 & 43.47 \\
\hline
\end{tabular}

* $\mathrm{SE}=\mathrm{Standard}$ error.

** AFI= Antifeedant index.
L.S.D. at
$5 \%$
$1 \%$
Treatments (T.)
$=0.24$
$=0.31$
Concentrations (C.)
$=0.35$
$=0.47$
T. x C.
$=0.44$
$=0.64$

Table (3): Effect of feeding of Spodoptera littoralis $4^{\text {th }}$ instar larvae on fungicide treated leaves for 24 hrs. (at the end of larval instar).

\begin{tabular}{|c|c|c|c|c|}
\hline \multirow{3}{*}{ Treatments } & $\begin{array}{c}\text { Conc. } \\
(\mathrm{ppm})\end{array}$ & $\begin{array}{c}\text { Mean larval weight } \\
(\mathrm{mg}) \pm \mathrm{SE} *\end{array}$ & $\begin{array}{c}\text { Mean larval duration } \\
(\text { days }) \pm \mathrm{SE}\end{array}$ & $\begin{array}{c}\text { Larval } \\
\text { mortality } \\
(\%)\end{array}$ \\
\hline Control & 00.00 & $1351.2 \pm 139$ & $11.38 \pm 0.47$ & 00.0 \\
\hline \multirow{5}{*}{ Toledo } & 01.00 & $1317.0 \pm 194$ & $11.45 \pm 0.39$ & 04.0 \\
\cline { 2 - 5 } & 05.00 & $1314.4 \pm 163$ & $11.75 \pm 0.56$ & 06.0 \\
\cline { 2 - 5 } & 10.00 & $1299.0 \pm 145$ & $11.97 \pm 0.50$ & 08.0 \\
\cline { 2 - 5 } & 25.00 & $1274.6 \pm 101$ & $12.21 \pm 0.36$ & 10.0 \\
\cline { 2 - 5 } & 50.00 & $1263.4 \pm 100$ & $12.43 \pm 0.41$ & 14.0 \\
\cline { 2 - 5 } & 100.00 & $1149.8 \pm 49$ & $12.56 \pm 0.32$ & 14.0 \\
\hline \multirow{4}{*}{$\begin{array}{c}\text { Amistar } \\
25 \% \text { SC }\end{array}$} & 125.00 & $1149.4 \pm 50$ & $12.74 \pm 0.34$ & 18.0 \\
\cline { 2 - 5 } & 01.0 & $1294.4 \pm 166$ & $11.74 \pm 0.40$ & 06.0 \\
\cline { 2 - 5 } & 05.0 & $1282.0 \pm 136$ & $12.06 \pm 0.51$ & 16.0 \\
\cline { 2 - 5 } & 10.0 & $1265.2 \pm 121$ & $12.20 \pm 0.49$ & 16.0 \\
\cline { 2 - 5 } & 25.0 & $1246.6 \pm 118$ & $12.39 \pm 0.46$ & 22.0 \\
\cline { 2 - 5 } & 50.0 & $1243.0 \pm 71$ & $12.80 \pm 0.24$ & 30.0 \\
\hline & 75.0 & $1150.0 \pm 52$ & $12.90 \pm 0.16$ & 34.0 \\
\hline
\end{tabular}

* $\mathrm{SE}=$ Standard error.
L.S.D. at
$5 \%$
$1 \%$
$5 \%$
$1 \%$
Treatments (T.)
$=059.15$
$=078.28$
$=0.26$
$=151.80=201.80$
$=0.52$
T. x C.
$=198.95$
$=250.73$
$=0.68$
$=0.34$
$=0.70$
$=0.98$ 
of larval instar of the $S$. littoralis insect in compared with the control treatment. The reduction in food consumption may be reduced the larval weight and also increased the larval duration. Some larval mortality was observed especially on the higher concentrations and this was more obvious with azoxystrobin than tebuconazole comparing with the control treatment.

The results in Table (4) cleared the effect of the tested compounds on pupation $\%$, pupal mortality \%, pupal duration (days) and adult emergence \%. From these results, the fungicides reduced pupation $\%$, adult emergence $\%$ and increased the pupal duration as well as pupal mortality $\%$ especially at higher concentrations. Azoxystrobin was more effective than tebuconazole in this respect.
The obtained results illustrated in Table (5) indicated the effect of treatments on reproductive parameters (fecundity and fertility) and sterility $\%$. These data revealed that the fungicides reduced the fecundity (egg laid female ${ }^{-1}$ ) and this was significantly observed in comparison with the control treatment. Also, these fungicides reduced the fertility (hatchability \%) and increased sterility $\%$ especially on higher concentrations.

The results in Table (6) showed the effect of the tested fungicides on longevity of males and females of $S$. littoralis insect. These data indicated that these compounds reduced longevity in comparison with control treatment. The reduction $\%$ in longevity was increased with the increase of concentration especially at the higher concentrations.

Table (4): Effect of feeding of Spodoptera littoralis $4^{\text {th }}$ instar larvae on fungicide treated leaves for 24 hrs. on pupal stage.

\begin{tabular}{|c|c|c|c|c|c|}
\hline Treatments & $\begin{array}{l}\text { Conc. } \\
\text { (ppm) }\end{array}$ & Pupation (\%) & $\begin{array}{l}\text { Mean pupal weight } \\
\quad(\mathrm{mg}) \pm \mathrm{SE}^{*}\end{array}$ & $\begin{array}{c}\text { Mean pupal } \\
\text { duration (days) } \pm \\
\text { SE }\end{array}$ & $\begin{array}{c}\text { Pupal } \\
\text { mortality }(\%)\end{array}$ \\
\hline Control & 00.00 & 100.0 & $386.6 \pm 8.6$ & $9.61 \pm 0.51$ & 02.0 \\
\hline \multirow{7}{*}{$\begin{array}{l}\text { Toledo } \\
43 \% \mathrm{SC}\end{array}$} & 01.00 & 96.0 & $386.8 \pm 6.7$ & $9.58 \pm 0.47$ & 02.0 \\
\hline & 05.00 & 94.0 & $379.8 \pm 12.5$ & $9.51 \pm 0.40$ & 03.0 \\
\hline & 10.00 & 92.0 & $377.4 \pm 19.4$ & $10.21 \pm 0.85$ & 05.0 \\
\hline & 25.00 & 90.0 & $370.6 \pm 11.9$ & $10.60 \pm 0.37$ & 07.0 \\
\hline & 50.00 & 86.0 & $373.2 \pm 16.1$ & $10.70 \pm 0.39$ & 10.0 \\
\hline & 100.00 & 86.0 & $375.6 \pm 13.8$ & $10.89 \pm 0.26$ & 11.0 \\
\hline & 125.00 & 82.0 & $368.6 \pm 11.5$ & $11.17 \pm 0.37$ & 17.0 \\
\hline \multirow{7}{*}{$\begin{array}{l}\text { Amistar } \\
25 \% \mathrm{SC}\end{array}$} & 01.0 & 94.0 & $384.8 \pm 6.5$ & $9.72 \pm 0.56$ & 02.0 \\
\hline & 05.0 & 84.0 & $376.8 \pm 11.4$ & $10.24 \pm 0.41$ & 03.0 \\
\hline & 10.0 & 84.0 & $376.6 \pm 17.3$ & $10.68 \pm 0.43$ & 08.0 \\
\hline & 25.0 & 78.0 & $369.2 \pm 12.9$ & $10.85 \pm 0.60$ & 11.0 \\
\hline & 50.0 & 70.0 & $375.0 \pm 12.6$ & $10.91 \pm 0.58$ & 16.0 \\
\hline & 75.0 & 66.0 & $356.6 \pm 9.8$ & $11.19 \pm 0.82$ & 18.0 \\
\hline & 100.0 & 62.0 & $364.0 \pm 13.3$ & $11.45 \pm 1.02$ & 22.0 \\
\hline
\end{tabular}

* SE= Standard error

L.S.D. at

Treatments (T.)

Concentrations (C.)

T. $\times$ C.

$\begin{array}{ccrr}\mathbf{5 \%} & \mathbf{1 \%} & \mathbf{5 \%} & \mathbf{1 \%} \\ =05.81 & =07.69 & =0.31 & =0.42 \\ =15.81 & =21.03 & =0.75 & =1.00 \\ =19.78 & =25.55 & =0.97 & =1.10\end{array}$


Table (5): Effect of feeding of Spodoptera littoralis $4^{\text {th }}$ instar larvae for $24 \mathrm{hrs}$. on fungicide treated leaves on adult emergence, reproductive parameters and sterility.

\begin{tabular}{|c|c|c|c|c|c|}
\hline Treatments & $\begin{array}{l}\text { Conc. } \\
\text { (ppm) }\end{array}$ & $\begin{array}{c}\text { Adult emergence } \\
(\%)\end{array}$ & $\begin{array}{c}\text { Fecundity } \\
\left(\text { eggs/female) } \pm \mathrm{SE}^{*}\right.\end{array}$ & $\begin{array}{c}\text { Fertility } \\
\text { (hatchability \%) }\end{array}$ & $\begin{array}{l}\text { Sterility } \\
(\%)\end{array}$ \\
\hline Control & 00.00 & 98.0 & $873 \pm 50$ & 97.13 & 00.00 \\
\hline \multirow{7}{*}{$\begin{array}{l}\text { Toledo } \\
43 \% \text { SC }\end{array}$} & 01.00 & 98.0 & $856 \pm 38$ & 97.12 & 02.00 \\
\hline & 05.00 & 97.0 & $842 \pm 33$ & 97.00 & 03.00 \\
\hline & 10.00 & 95.0 & $801 \pm 66$ & 96.43 & 08.00 \\
\hline & 25.00 & 93.0 & $692 \pm 53$ & 96.11 & 21.65 \\
\hline & 50.00 & 90.0 & $662 \pm 52$ & 96.00 & 25.11 \\
\hline & 100.00 & 89.0 & $614 \pm 25$ & 93.00 & 32.71 \\
\hline & 125.00 & 83.0 & $610 \pm 23$ & 91.00 & 34.57 \\
\hline \multirow{7}{*}{$\begin{array}{l}\text { Amistar } \\
25 \% \text { SC }\end{array}$} & 01.0 & 98.0 & $845 \pm 35$ & 96.11 & 04.27 \\
\hline & 05.0 & 97.0 & $833 \pm 33$ & 93.26 & 08.45 \\
\hline & 10.0 & 92.0 & \multirow{2}{*}{$\frac{786 \pm 56}{782 \pm 55}$} & 91.22 & 15.53 \\
\hline & 25.0 & 89.0 & & 89.70 & 17.33 \\
\hline & 50.0 & 84.0 & $658 \pm 52$ & 88.13 & 31.66 \\
\hline & 75.0 & 82.0 & $626 \pm 39$ & 86.15 & 36.43 \\
\hline & 100.0 & 78.0 & $610 \pm 31$ & 81.14 & 41.69 \\
\hline \multicolumn{6}{|c|}{$* \mathrm{SE}=\mathrm{Standard}$ error } \\
\hline \multirow{2}{*}{\multicolumn{3}{|c|}{$\begin{array}{l}\text { L.S.D. at } \\
\text { Treatments (T.) }\end{array}$}} & \multirow{2}{*}{\multicolumn{3}{|c|}{$\begin{array}{cc}\mathbf{5 \%} & \mathbf{1 \%} \\
=044.77 & =059.25\end{array}$}} \\
\hline & & & & & \\
\hline \multicolumn{3}{|c|}{ Concentrations (C.) } & \multicolumn{3}{|l|}{$=107.13$} \\
\hline \multicolumn{3}{|c|}{ T. $\times$ C. } & \multicolumn{3}{|l|}{$=134.79$} \\
\hline
\end{tabular}

Table (6): Effect of feeding of Spodoptera littoralis $4^{\text {th }}$ instar larvae for $24 \mathrm{hrs}$. on fungicide treated leaves on male and female longevity of adults.

\begin{tabular}{|c|c|c|c|c|c|}
\hline Treatments & $\begin{array}{l}\text { Conc. } \\
\text { (ppm) }\end{array}$ & $\begin{array}{l}\text { Male longevity } \\
\text { (day) } \pm \mathrm{SE}^{*}\end{array}$ & $\begin{array}{l}\text { Male longevity } \\
\text { reduction \% }\end{array}$ & $\begin{array}{c}\text { Female } \\
\text { longevity } \\
\text { (day) } \pm \mathrm{SE}^{*}\end{array}$ & $\begin{array}{c}\text { Female } \\
\text { longevity } \\
\text { reduction \% }\end{array}$ \\
\hline Control & 00.00 & $12.3 \pm 0.3$ & 00.00 & $11.7 \pm 0.3$ & 00.00 \\
\hline \multirow{7}{*}{$\begin{array}{l}\text { Toledo } \\
43 \% \text { SC }\end{array}$} & 01.00 & $12.1 \pm 0.1$ & 01.90 & $11.8 \pm 0.3$ & 00.00 \\
\hline & 05.00 & $11.9 \pm 0.3$ & 03.60 & $11.3 \pm 0.6$ & 03.10 \\
\hline & 10.00 & $11.8 \pm 0.2$ & 04.20 & $11.1 \pm 0.4$ & 05.30 \\
\hline & 25.00 & $10.8 \pm 1.0$ & 12.20 & $10.8 \pm 0.4$ & 07.50 \\
\hline & 50.00 & $10.5 \pm 0.5$ & 14.60 & $9.9 \pm 0.3$ & 15.20 \\
\hline & 100.00 & $10.0 \pm 0.7$ & 18.70 & $9.7 \pm 0.4$ & 16.90 \\
\hline & 125.00 & $9.3 \pm 0.5$ & 24.40 & $9.7 \pm 0 . \varepsilon$ & 22.70 \\
\hline \multirow{7}{*}{$\begin{array}{l}\text { Amistar } \\
25 \% \text { SC }\end{array}$} & 01.0 & $11.0 \pm 0.9$ & 10.60 & $11.6 \pm 0.2$ & 00.90 \\
\hline & 05.0 & $10.6 \pm 0.5$ & 14.00 & $11.2 \pm 0.5$ & 03.90 \\
\hline & 10.0 & $10.3 \pm 1.2$ & 16.70 & $10.6 \pm 0.6$ & 09.60 \\
\hline & 25.0 & $9.3 \pm 1.5$ & 24.70 & $10.6 \pm 0.6$ & 09.20 \\
\hline & 50.0 & $9.0 \pm 0.9$ & 27.30 & $9.6 \pm 0.3$ & 17.80 \\
\hline & 75.0 & $8.6 \pm 0.8$ & 30.00 & $9.6 \pm 0.4$ & 18.10 \\
\hline & 100.0 & $8.2 \pm 0.5$ & 33.30 & $9.6 \pm 0.4$ & 18.10 \\
\hline \multicolumn{6}{|c|}{$* \mathrm{SE}=\mathrm{Standard}$ error } \\
\hline L.S.D. at & & $5 \%$ & & $5 \%$ & $1 \%$ \\
\hline \multicolumn{2}{|c|}{ Treatments (T.) } & $=0.48$ & & $=1.00$ & $=01.33$ \\
\hline \multicolumn{2}{|c|}{ Concentrations (C.) } & $=0.97$ & & $=0.52$ & $=00.70$ \\
\hline \multicolumn{2}{|c|}{ T. x C. } & $=1.07$ & & $=1.04$ & $=18.71$ \\
\hline
\end{tabular}




\section{DISCUSSION}

The tested fungicides (azoxystrobin and tebuconazole) were investigated for their possible interaction with the biological aspects of the ECLW when sprayed on solanaceae crops. These fungicides clearly reduced feeding ratio of this insect and reduced the average weight of consumed leaves larva ${ }^{-1}$ when treated with different concentrations of two fungicides. The reduction in consumed leaves and feeding ratio may be due to these compounds exhibited antifeeding properties on ECLW larvae and the reduction in larval weight may be due to the reduction in consumed leaves. Also, these compounds affect the pupal and adult stages and caused considerable damage on the growth and development of this insect from the fourth instar larvae until the adult stage.

The results in this study indicated that the fungicides may cause toxic effects on ECLW insect and affected the growth and development. The relative differences in this study are probable related to the differences in fungicide concentrations, the structure and chemical group and the site of action in $S$. littoralis insect.

These results are in accordance with those reported by many authors. Chalfant (1977) found that the Guazatine fungicide caused significant reduction in feeding in insect pests. Abdel-Aziz, Shadia and Mohamed (2002) reported that Euparen $\mathrm{M}$ fungicide was very effective in reducing the feeding of $S$. littoralis larvae followed by Galbin Copper, Rizolex and Dithane M-45, respectively. El-Kholy (2005) mentioned that the tested fungicides reduced the feeding ratio of $4^{\text {th }}$ instar larvae of $S$. littoralis and this was more obvious with Sulphur and Dithane M-45, Delcup, Topas 100 and Domark. El-Sisi et al. (2016) concluded that besides using the fungicides, they showed slightly initial and latent effects against second and fourth instar larvae of $S$. littoralis and high developmental effect against both pupae and moth stages enough to broke the insect lifecycle especially in case of Copper Sulphate and Copper Oxychloride especially $2^{\text {nd }}$ instar larvae of this insect. Srivastava et al. (2017) mentioned that Ridomil MZ affect the growth and development of $S$. litura at higher concentrations. They added that larval duration and its mortality increased with increase in the level of fungicides. The larval duration was significantly prolonged. Also, the increase in fungicide concentration showed the marked decrease in pupal stage and adult emergence indicating a significant correlation between adult emergence $\%$ and concentration. The lowest pupation rate, adult emergence, the longevity of adults and fecundity was recorded with Ridomil MZ treated larvae. The reduction in fecundity may be due to disfunction of maturation of an insect egg which depend on the materials that are synthesized by the ovary in suit which includes protein, lipids and carbohydrates all of which required for the embryonic structure (Shaurub et al., 1998).

In conclusion, the data revealed that these fungicides may be affect the physiological and biochemical process and also fungicides can serve a practical tool to reduce the $S$. littoralis populations and may assume a greater role integrated programs showed to the manage insect pests and diseases.

\section{REFERENCES}

Abbott, M. S. (1925). A method of computing the effectiveness of an insecticides. J. Econ. Entomol., 18: 265 - 267.

Abd El-Aziz, Shadia E. and A. N. Mohamed (2002). Non-target effects of some fungicides used on pepper (Capsicum frutescens) cultivated in greenhouses on the developmental stages of Spodoptera littoralis (Boisd.). Bull. Ent. Soc. Egypt, Econ. Ser., 28: 67 - 79.

Adamski, Z. and K. Ziemnicki (2004). Side effects of mancozeb on Spodoptera exigua (Hübn.) larvae. J. Appl. Entomol., 128: 212 - 217.

Bayoumi, A. A., R. Balana-Fouce, A. K. Sobeiha and E. M. K. Hussein (1998). The biological activity of some chitin synthesis inhibitors against the cotton leafworm Spodoptera littoralis (Boisduval), (Lepidoptera: Noctuidae). Bol. Sanid Vegetal Plagas, 24: 499 - 506.

Chalfant, R. B., J. W. Todd, W. K. Taylor and B. Mullinix (1977). Laboratory studies on the antifeeding effect of a fungicide, Guazatine, on 
eleven species of phytophagous insects. J. Econ. Entomol., 70 (4): 513 - 517.

Delpueech, J. M. and R. Allemand (2011). Side effects of fungicides on the abundance and the species diversity of the natural populations of Drosophila and their hymenopterous parasitoids in orchards. Phytoparasitica, 39: 429-435.

El-Defrawi, M. E., A. Toppozada, N. Mansour and M. Zeid (1964). Toxicological studies on the Egyptian cotton leafworm, Prodenia litura. I. Susceptibility of different larval instars to insecticides. J. Econ. Entomol., 57: 591 - 593.

El-Kholy, R. M. A. (2005). Nontarget effects of fungicides on some biological aspects of the cotton leafworm, Spodoptera littoralis (Boisd.). AlAzhar J. Agric. Res., 42: 79 - 93.

El-Sheikh, E. A. (2015). Comparative toxicity and sublethal effects of emamectin benzoate, lufenuron and spinosad on Spodoptera littoralis (Boisd.) (Lepidoptera: Noctuidae). Crop Prot., 67: 228 - 234.

El-Sisi, A. G., Abd-Allah, Amal, A. and Heikal, Gamila, A. (2016). Side effects of some recommended cupreous fungicides against cotton leafworm infested bean seedlings. Egypt. Acad. J. Biol. Sci., 8 (1): 127 - 131.

Ghanema, Hoda, A. E. (2002). Studies on the environmental toxicity of some insecticides among the cotton leafworm, Spodoptera littoralis (Boisd.). Ph. D. Thesis, Agric. College, Moshtohor, Zagazig Univ., 163 pp.

Gomez, K. A. And A. A. Gomez (1984). Statistical procedures for agriculture research. J. Wileg and Sons. Inc., New York, $2^{\text {nd }}$ Ed.

Hosny, M. M., C. P. Topper, G. G. Moawad and G. B. El-Saadany (1986). Economic damage thresholds of Spodoptera littoralis (Boisd.) (Lepidoptera: Noctuidae) on cotton in Egypt. Crop Prot., 5: 100 - 104.

Khidr, A. A., A. O. Abdeen, M. A. Eissa, A. M. H. Azab and A. I. Hassan (2003). Evaluation of some insecticides and their joint action against the cotton leafworm, Spodoptera littoralis (Boisd.) on lettuce vegetable plants, Lactuca sativa L. Ann. Agric. Sci., Moshtohor, 41 (3): 1323 - 1330.

Meisner, J. and N. E. Nemny (1992). The effect of margosan-O on the development of the Egyptian cotton leafworm, Spodoptera littoralis (Boisd.) (Lepidoptera: Noctuidae). J. Appl. Entomol., 113 (4): 330 - 333.

Pavela, R., N. Vrchotova and B. Sera (2008). Growth inhibitory effect of extracts from Reymoutria sp. Plants against Spodoptera littoralis larvae. Agrociencia, 42: 573 - 584.
Pineda, S., M. Schneider, G. Smagghe, A. Martinez, P. D. Estal, E. Vinuela, J. Valle and F. Budia (2007). Lethal and sublethal effects of methoxyfenozide and spinosad on Spodoptera littoralis (Lepidoptera: Noctuidae). J. Econ. Entomol., 100: 773 - 780.

Pratissoli, D., A. M. Milanez, W. F. Barbosa, F. N. Celestino, G. S. Andrade and R. A. Polanczyk (2010). Side effects of fungicides used in cucurbitaceous crop on Trichogramma atopovirilia Oatman \& Platner (Hymenoptera: Trichogramatidae). Chilean J. Agric. Res., 70 (2): 323 - 327.

Said, A. A. A., F. A. Shaheen, E. A. H. Sherief and H. A. M. Fouad (2012). Estimation of certain compounds against cotton leafworm, Spodoptera littoralis (Boisd.) on sugar beet plants. J. Plant Prot. and Path., Mansoura Univ., 3 (12) : 1321 - 1330.

Saleh, A. A., Elgohary, Laila R., W. M. Watson and A. S. El-Abassy (2015). Toxicity of some conventional and nonconventional insecticides against cotton leafworm, Spodoptera littoralis (Boisd.). J. Pl. Prot. and Path., Mansoura Univ., 6 (4): $663-673$.

Shaurub, E. H., Z. A. Ahmed and E. M. Samira (1998). Impacts of pyriproxyfen and extracts of Schinus terebinthifolins on development, reproduction and reproductive organs in Spodoptera littoralis. J. Egypt. Ger. Soc. Zool., (E): 57 - 82.

Sherief, E. A. H., Abd-El-Basier, Saadia A. and S. H. A. Hussein (2009). The economic injury level of Spodoptera littoralis (Bosid.) and toxic effect of certain compounds on sugar beet at Fayoum Governorate. Egypt. J. Appl. Sci., 24(8): 663-693.

Srivastava, K., S. Sharma, D. Sharma and R. Kumar (2017). Effect of fungicides on growth and development of Spodoptera litura. Int. J. Life. Sci. Scientific Res., 3 (2): 905 - 908.

Toppozada, A. S. Abdallah and M. E. ElDefrawi (1966). Chemosterilization of larvae and adults of the Egyptian cotton leafworm Prodenia litura, by Apholate, Metepa, and Tepa. J. Econ. Entomol., 59: 1125 - 1128.

Wada, K. and K. Manukata (1968). Naturally occurring insect control chemicals. Isoboldine, a feeding inhibitor and cocculolidine, an insecticide in the leaves of Cocculus trilobus DC. J. Agric. Food Chem., 16: 471 - 474.

Wahba, E. A. (2016). Effect of tebufenozide and diflubenzuron on some biological aspects of cotton leafworm Spodoptera littoralis (Boisd.) comparison with chlorpyrifos. J. Pl. Prot. and Path., Mansoura Univ., 7 (3): 193 - 198. 
التأثيرات الجانبية لمبيدي الفطريات أزوكسي ستروبين وتيبوكونازول علي دودة ورق القطن المصرية تحث الظروف المعملية.

رمضان مصطفي عبده الخولي' - محمود محمد محمد البمبي' - محمود محروس محمود الحصاوي' ا ــ قسم وقاية النبات ـ كلية الزراعة بالقاهرة - جامعة الأزهر. r. قسم البيئة والزراعة الحيوية ـ كلية الزراعة بالقاهرة - جامعة الأزهر. الملخص العربي

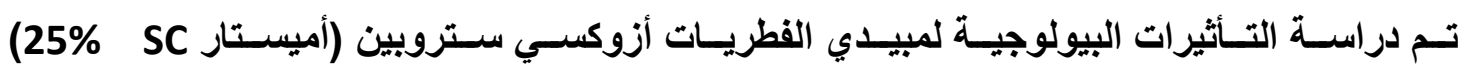
وتيبوكونـازول (توليدو 43\% SC) علـي بعض العمليـات الحيويـة للدودة ورق القطن المصرية بالمقارنـة بالكنترول تحت الظروف المعملية. تمت تغذيـة يرقات العمر الرابع علي أوراق خروع معاملـة بتركيزات مختلفة من المركبات السابقة لمدة ؟ ب سـاعة وتم قياس معدل الإستهلاك الغذائي لليرقات حتى التعذير. أوضحت النتائج أن مبيدات الفطريات المستخدمة تنقص من وزن الغذاء المستهلك لكل يرقة وتنقص من معدل التغذية. وكان مبيد أزوكسي ستروبين أكثر فاعلية من مبيد تيبوكونـازول خصوصاً علي التركيزات العالية. كمـا أوضحت النتائج أيضـاً أن هذه المركبـات تنقص من وزن اليرقات المعاملـة وتزيــ من معدل موت اليرقات وطول مدة العمر اليرقي. وبينت النتائج أن هذه المركبات تنقص من النسبة المئويـة للتعذير وتزيلـ من مدة عمر العذارى. أمسا تأثير هذه المركبات علي الحشرات الكاملـة فقد أوضحت النتائج أنها تنقص من عدد البيض الموضوع لكل أنثي وتنقص نسبة الخصوبة وتزيـا من معدل العقم. كمـا أن هذه المركبات تنقص من طول فترة عمر الفراشات الأكور والإناث.

وعموماً وفي كل الحالات فإن التأثيرات السامة لمبيدي الفطريات أزوكسي ستروبين وتيبوكونازول علي

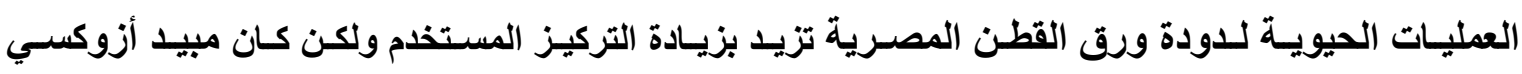
ستروبين أكثر فاعلية من مبيد تيبوكونازول علي العمليات الحيوية لدودة ورق القطن المصرية. الكلمات المفتاحية: التأثيرات الجانبيـة ـ أزوكسي ستروبين - تيبوكونـازول ـ التأثيرات البيولوجيـة ـ دودة ورق القطن المصرية. 